\section{The Peculiarities of Foreign Experience Using in Industrial-Financial Groups Forming Under the Conditions of Ukraine Entering the EU}

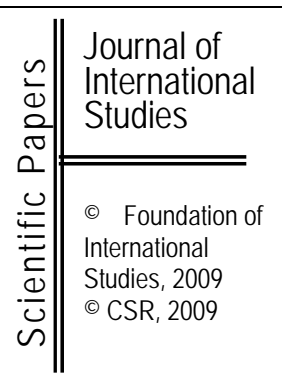

\author{
Olga Boryk \\ Associate professor of Economy enterprises \\ department \\ Ternopil Institute of Social and Informational \\ Technologies \\ boryk_olya@,ukr.net
}

\begin{abstract}
The experience of the industrial-financial groups forming in the conditions of European Union, Commonwealth of Independent States (CIS) and the USA has been characterized in the article. Positive and negative moments of this process are reflected. Ways and terms of its using
\end{abstract}

Key words: the industrial-financial groups (IFG), the main enterprise of IFG, participant of IFG

JEL classification: O25, P1, P51

\title{
The problem actuality
}

The analysis of IFG researches showed the importance of studying and planning of foreign experience in creation and the IFG functioning in the terms of the home system of economy support for the sake of industrial, labour, natural and financial potential rational using of Ukrainian economy.

Forming and the IFG functioning problems in Ukraine are attracted by all greater attention of mass, public, scientific economists' mediums. Alekseev I.V., Andrushco N.I., Andrushciv B.M., Besarab E.O., Buryac P.Yo., Culish G.P., Mandrel O.G., Pogribniy I.Y. and others have done the great importance in research of the IFG subject. Pogribniy I.Y. has paid his attention on necessity of approaching of Ukrainian economy to the world system of economy support with the purpose of its best achievements using in the economy management, the presentation of national interests at the today's international markets does not cause the doubt not only at reformers and officials, but also at the wide circle of specialists, managers.

\section{The main results of the investigation}


In the conditions of economic recession in the antichrists management it is necessary to attract backlogs that assist the integrations of financial and industrial capital, inside the country and with bringing home and foreign investments in.

Efficiency of financial and industrial capital integration was already acknowledged on the first stage of economic reformation in Ukraine. The first attempts of commercial banks creation with the stock associations complement, in particular such as joint-stock company "Concern Electron", joint-stock company "Conveyer", confirmed expedience of such integration.

The experience of financial and industrial capital integration led that IFG organization is a perfect and modern form. One of first attempts of such structures organization in Ukraine was carried out in the 1994 year. Some of the large factories-producers of naphtha gas equipment - "Carpatnaphthomash", the Drogobitch factory of boring chisels, the Crivoriz turbine factory with Ucrsotsbancom joint-stock company created "Industrial-financial group" (IFG), charging a management to the marketing firm "Fantal". Then Ucrinbank joined to them latter. The interest of industrial enterprises and financial structures to their union in IFG constantly grows.

In the USA the combination of banks, industrial and commercial companies and, for example, corporations was carried out first of all through the presence of communications in the field of finances. In the first half of XX age due to the concentration of capital the domestic (Morgan, Rocfeleri, Dyoponi, Melloni and etc.) and regional (Chicago, Cleveland, California and etc.) financial groups succeed to concentrate the considerable share holding and unite industrial and commercial companies of different types of activity with the subsequent interlacing of their communications with the help of not only joint-stock but also personal, domestic and other relations. But the interlacement of bank and unfinancial structures resulted in expansion of banks services and reliability rising of capital investment. Thus, the banks began to provide consultative services (legal, economic and others like that), edging out specialized consultative companies, leasing (allotting credits under the leasing equipment) and project (assuming charges in relation to realization of production project) providing, giving to the clients service in principle of the most complete service (all only at us and our partners, that is if the client needs unfinancial services - bank gives them through its partners on the group).

Industrial-financial ("General motors", "Ford motor", ITT, IBM and others like that) and commercial - financial direction conglomerates ("Grey Robac", "Kroger" and other) are created.

So, in the USA join around the definite kernel (bank, commercial or industrial) are very popular, that determine the industrial - financial policy of country generally, and practically control development of important economy industries. However, it should be marked the display of new tendencies, especially the confluence of unions in the more large coalitions (union of national scale). We refer to them California (western) and New York (east), and in the definite measure north (industrial) groups.

A territorial division of these groups is just convention because they join industrial giants, which have enterprises through the all country. For example, California group together with the banks ("Bank of America", "First Intersane", "Security pacific", "Holes Fargo"), unite such well known concerns as "Lucite", "Rockwell international", "Hewlett-Packard", "Chevron" and others. Practically each of foregoing business concerns is a kernel of union, but enough close intercommunication between them are created not so much due to the domain and direct control after companies and establishments, as by collaboration in the sole economic space. However, along with that the active development of local groups goes, which operate within bounds of region or industry (for example, regional - Texas, industrial naphtha recast). 
The German industrial-financial unions carry substantial weight on the economy of country and, unlike the groups of the USA, immediately co-operate with the state structures in development of country industrial potential. The peculiarities of the German industrialfinancial groups becoming are interlinked with the features of German post-war economy foundation in the whole. It went out from crisis thanks to the program of the Gerhard professor, which had more financial, than production orientation.

That's why the industrial-financial German groups are based round the bank kernel. For today, the banks for the account partly domain, partly - personal union with the industrial, insurance and auction unions and concerns control the greatest part of country industry. Three national groups control more than half part of industry, transport, credit insurance sphere, trade, services sphere and others like that.

The most powerful among them is the group that unites around "Douche Bank" business concerns "Siemens", "Bosh", "Daimler Bents", "Tisane", FEBA and many others. The second after the power is a group concentrated around "Dresden bank". Well known business concerns belong to this group, as "Hest", "Gryondig", "Croup" and other. This group has close communications with regional, first of all with Bavarian ("Dresden bank" is connected with "Bearish Hypotheses found Vex ell bank" by personal contract), and with the foreign (France, Belgium, Golandiya, the USA and others like that) groups. Industrialfinancial group that is based round the "Comerts bank" specializes in trade and services sphere. But considerable part of economic space of Germany is controlled by the regional financial industrial groups. These groups are interlinked with the governments of lands that have a considerable autonomy from the federal government and legislation, and co-operate with them in directions of regional economy development.

Exactly in Japan the financial industrial groups tested the successive development and an effect of their using was maximal. Historically at ends of 40th enterprise groups "kejrecu" (by that time on their organization they only approached to the corporations) began to unite in the financial industrial groups - "syudan". In composition of groups entered, except of the production structures, and financial (banks, insurance companies and others like that). So, for example, in the union of "Mitsubishi" "Mitsubishi dzyoco" holds the share (but which make only a few percents) of the bank "Mitsubishi junco", companies from lifeinsurance "Maids seamy", companies from the risk types of insurance of "Sumimoto ceydzyo casai hocen", trust-bank "Mitsubishi sintacu", companies "Tokyo caydz Casey", "Mitsubishi sedzi", "Mitsubishi dance" and other. Practically Board of directors of "Sudan" that consists of directors of these firms and companies, and is a handling organ of "Sudan", which is not formal legally, operates as a continuous economic organism.

To this assists also and system of placing actions, according to which the Japanese company places its actions at partners only. For Japan fascination of companies by acquisition of controlling interest is typical phenomenon. If somebody wants to be delivered actions of firm or company, he warns about his desires preliminary and a company is looking for him a buyer among its partners or clients, as a rule, members of it "Sudan".

Practically the most Japanese corporations, credit-financial and insurance companies and establishments, sales houses and firms are incorporated in the industrial-financial groups "Sudan". Seven of them really control an economic situation in the most industries of economy of country. Three of them created round the industrial corporations: "Mitsui", "Sumimoto" and "Mitsubishi"; other four - round the banks of "Nihon cogyo junco", "Fudzi" (the "Faye" group), "Sanva" and "Dayti-Cangyo". Among them we have independent industrial group "Hitachi-Nissan", metallurgical business concern of "Sin Nippon seytetsu", powerful energetic, chemical and naphtho-restructed corporations. Only this group has status of legal entity unlike the other groups. Every group specializes in one or a few industries of economy. 
The primary forming of groups in France was carried out by the union of domestic and individual capital. Exactly domestic documents and communications along with the agreements systems about the sale markets and deliveries, credit-financial and investivegarantee relations, production technological and research collaboration in case of absolute directed support by the imperious structures allowed forming a kernel of industrial-financial groups. A few competitive productions coexist in French industry in every industry, the considerable part from which has different forms of owning.

So, the state financial industrial groups are based on the such powerful business concerns and companies, as: "Electricity de France", "Gas de France", "Alcotel", "Reno", "Yozinor-Sasilor", "Elf-Aciten" and other. The state companies and business concerns operate in the industries related to the heavy industry: in chemical - "Ron-Pulenc"; in metallurgical general type - "Yozino-Sasilor", in specialized - on aluminum - "Peshine", on zinc, nickel and lead - "Imetal"; in airspace, automobile- and machine-building, electronic, naphtha-restructed and others like that. But along with the state corporations successfully operate and have state support .

So, in the motor industry private company "Pego" successfully competes with the state corporation "Reno". Thus, French experience connects different elements (state and private forms of owning, different systems of management and development, elements of planning and hard state adjusting and support, family and regional territorial copulas and system of cooperation and collaboration).

Original is the system of industrial-financial groups' construction. Although in case of groups' management the multidivisional (variant of matrix) system is used, a base element is a kernel, by the basis of which is production industrial corporation or trade union. Thus unlike the American or German system a bank is not a dominant element of the system "industrialfinancial group".

Economy practically in all entire developed western countries and so called "young tigers" in any case is related to becoming in these countries of industrial-financial groups. In some countries leading role in case of forming groups plays the state, in other it is bank, industrial or family capital. In a part of countries the industrial-financial groups act the leading role in all economy of the country, in other - the groups control only definite part of industry. So, in Switzerland, Hong Kong, Singapore it is allowed to work to those national groups more effectively that are gradually transformed in international. Thus the groups union can be carried out round the domestic personal capital.

Today Korea enters to the group of countries that have the greatest rates of development and after a lot of indexes was included in the group of developed countries. One of important instrument of achievement of such economic position was the financial industrial groups - "cheboli", which are under the care of government of Korea. It should be noted that in 80 - 90th it has happened the co-operation of some parts of "cheboley" with the international corporations with the purpose of conquest of the definite positions in some industries on the world market. For example, motor industry and production of computers "Devout" enterprise co-operates with the "Caterpillar" and "Pontiac" corporations; "Samsung" in production of domestic products, computers and equipment to them - with "General electric", IBM, "Compaq", "Olivetti", ATT; "Lacy Gold star" in production of television sets, telephone systems, video players co-operates with the "Magnavoce" corporations, "General electric", "Booths industrial corp.", "Vodavi technology"; "Hendy" in computers production with "Yonidentifay".

Italian industrial-financial groups control relatively the small economic space, first of all in the motor, chemical and machine-building industry, and also in equipment building. The kernel of group serves the bank financial or state holding. The state holdings were formed in case of the state financial-credit system support. 
So, five banks, which fully belong to the state (Neapolitan, Sicilian, Italian, "Monte dey Psci di Siena" and "Institutor binary dignity Piolo di Torina") and three, a package control of which belongs to the state business concern, are apart of the industrial reconstruction IRI (Roman, Italian credit and the Commercial bank), practically control basic financial streams in the country. Different directed industrial projects does not allow to inculcate each of them effectively, that resulted in the rise of organizational charges, grow bureaucratic vehicle, decline of flexibility and management efficiency, efficient of reaction on the economic situation changes, using efficiency of resources and others like that.

This is up to the most private industrial-financial group FIAT, which except for the motor industry and machine building unites the enterprises of television, telegraph and telephone apparatus, shipbuilding (gas turbines and turbo generators), aircraft building (aircraft and engines for them), railway transport, publishing activity.

In Russia, in the conditions of unique form of owning - state, union were formed mainly on initiative central organs of management on the industry or territorial industry principles and had a definite orientation. The necessity of creation of the new integration forming, structure and mechanism of functioning of which would have been adapted to the new market environment, resulted in holding organization, and in future and industrialfinancial groups. A kernel of such forming was either industry structures of management, which in future made a basis of holding, or banks.

Creation of most groups was carried out in industries of machine building, heavy industry and defensive industry. It should be mentioned that the IFG row are formed on the territorial economic bases, having for an object independently to work out the problems of financing and production development. Among such it follows to mark the "URAL-DRAGFEG" group, which is created in Yekaterinburg on the base of enterprises and productions, which unite a complete cycle.

\section{Conclusions and prospects of subsequent researches.}

Forming of purpose industrial-financial groups can become a mean of industries exiting of national economy from the crisis situation. The short analysis of possible organizational structure of purpose financial industrial group shows that effective activity of such unions possible only then when achievement of primary purpose with the concrete sub purposes advantageous both to every its participant in particular, and to them all together [5]. Thus, study of forming and work experience, both foreign and home industrial-financial groups ground to claim that on the given time the process of their forming takes place without proper scientific studying and consideration of education experience and functioning such structures, for example, in Japan, Germany, the USA.

Coming from these reasoning, the subsequent development of research would had been to provide for:

- indexes exposure of the purpose IFG competitiveness;

- machineries development and economic instruments influence on factors, which secure the effective management by them;

- development of conceptual bases of a principle model forming of the purpose IFG functioning in the context of requirements to the similar industrial-financial unions of the European standard.

On the basis of foregoing - with the purpose of assistance to activity of researches, forming and development of purpose industrial-financial groups, going out from the present raw material resource base and scientific intellectual potential, for the decision of mentioned problems and revival in particular of machine-building industry, expediently to foresee on the given stage the system of fiscal and credit benefits. 
The experience of different countries testifies to the different ways introduction of structural alteration and of its using it is to be substantially adjusted taking into account the features of concrete country, political and economic situation, and mentality of peoples.

\section{REFERENCES:}

1. The law of Ukraine „About the industrial-financial groups in Ukraine” $N$ 438/95-BP from 21.11.95 Information of Verhovna Rada (IVR), 1996, N 23, ст. 88. With changes from 20.11.2003, IVR, 2004, N 13, ст.181.

2. Boryk O.Y. The peculiarities of industrial-financial groups forming in the context of market relation building in Ukraine and the state entrance to EU // Announcer of the National university "Lviv Politexnik" "Management and enterprising in Ukraine: the forming stages and the development problems". -- 2007. -- №599, P. 78-85.

3. Pogribnuj I.Y. The industrial-financial groups and national industry development. The science methodological problems of forming, building and development. Manual Lviv. Institute of internal affairs at the Ukrainian academy of internal affairs. 1996. $89 \mathrm{p}$.

4. Derevjanko B. To the question of the industrial-financial groups forming // Enterprise, economy and law.. - 2003. - № 6. - C.12 - 16

5. Kostjuk A., Kostjuk E., Chernyshov K. The industrial-financial groups on the market of corporative control and inveting in Ukraine // The problem of thoeory and practice management.—2005. -- № 2,3

6. The industrial-financial groups as a model of cooperation of real and finance branches of economy: the real experiance. // Every week analitical view . 1999. № 2 (15-21 March).

7. Cvetkov V.A. The peculiarities of forming and perspectives of development $\mathrm{Of}$ the main types of Russian industrial-financial groups//The enterprise policy in Russia. -2002. -- №3. 